それによると 5 年以上経過例では，骨化の上下への 進畏，狭小率の增大共，異常に大きくなり $66 \%$.を占 める. また, 臨床症状覀化例も， 5 年以上経過例 で は，症状悪化例か～ $60 \%$ 以上を示す．次に質問をお碩 いします。

1）骨化型により骨化の進圆に差があるか.

2) 骨化の急性増殖があり得るか.

3）手術例と非手術例に骨化の進展に差方゙あるか.

解 答臂监島大学整形 川村 英俊

1）骨化型の分類と骨化の進展との関係については 特に差異はありません。

2）骨化が急速に進展した例があるかについては,
6 力月以内に粟粒大の骨化が，椎体高位内で上方へ進 展を認めた, 分節型の1例があります。

3）手術例と保存例とに進展の差は特にありませ h.

解 答留児島大学整形 翼村吉十郎

私共は, 観血療法として, 主に椎体严全摘により, 骨化栄を切除する前方除圧を主体に行なっている．前 方除玨後，固定椎間より上に，10\%前後の 連続型の 骨化陰影の出現した 1 例を経跧している．保存的治療 として，入院による頭蓋直達牽引を行ない，症状の軽 快をみた例もあるので, 頸椎後綎勒帯骨化症に対して も，術前に保存的療法を試みている。

\title{
腰部脊椎管狭窄の興味ある手術症例について
}

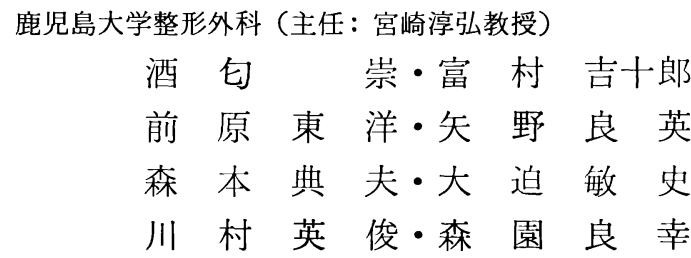

今給黎病院整形外科

今給黎尚典

\section{Narrowed Lumbar Canal Surgically Treated in Our Clinic}

By

T. Sakou, K. Tomimura, T. Maehara, Y. Yano,

N. Morimoto, S. Osako, H. Kawamura, Y. Morizono and T. Imakyure

Department of Orthopedic Surgery, Faculty of Medicine, Kagoshima University (Director: Prof. A. Miyazaki, M. D.)

\footnotetext{
About sixty cases of lumbar canal stenosis have been operated on in our clinic. Some of these patients, who had interesting clinical manifestations, were presented and the problems to do with this condition were discussed. Low back pain, sciatic pain and intermittent claudication had developed commonly in this disease, but priapism and neurotrophic dermal ulcer were found in a few cases. Recently we have been examining intrathecal condition on laminectomy, and the adhesion of the arachinoidal membrane were found more or less in many patients and some of them showed a higher degree of adhesive arachinoiditis.
} 
捧椎管狭小という病態関する記载仕かなり以前か らあるが, 1954年 Verbiest の developmental narrowing of the lumbar canal の報告以来, 㴗部脊 椎管狄窄に関する慜識が高まり多くの報告がひられる ようになった。しかしその概念や治療に関してはまだ 若干の問題を残している。昭和 48 年以降, 当科标上 び当科関連病院における腰部背椎管狭窄の手術症例は 約 60 例である. その内訳は developmental 3 例, spondylotic 31 例は, spondylolisthetic 24 例, iatrogenic 2 例であった。今回，われわれは興味ある臨 宋症状它旺した症例や治療上問題点のあった症例赏報 告し若干の考察を加兄る.

\section{症例}

症例 1.54 才，女子，主婦. 頸椎症性命骾症の合 併例. 昭和 45 年 3 月上り誘因なく頸部痛, 腰痛, 手 足のしびれ, 手指のIF緻運動障害などが出現し, 昭和 48 年 3 月より間歇性跛行, 一下胶のしびれが増強し, 昭和 49 年 6 月 当科入院. 入院時, 四肢の煺反射元 進, 上技の病的反射, 両上・下肢に知覚障害をみる。 X線所見では，第4婹椎に前方迄があり，ミエログ
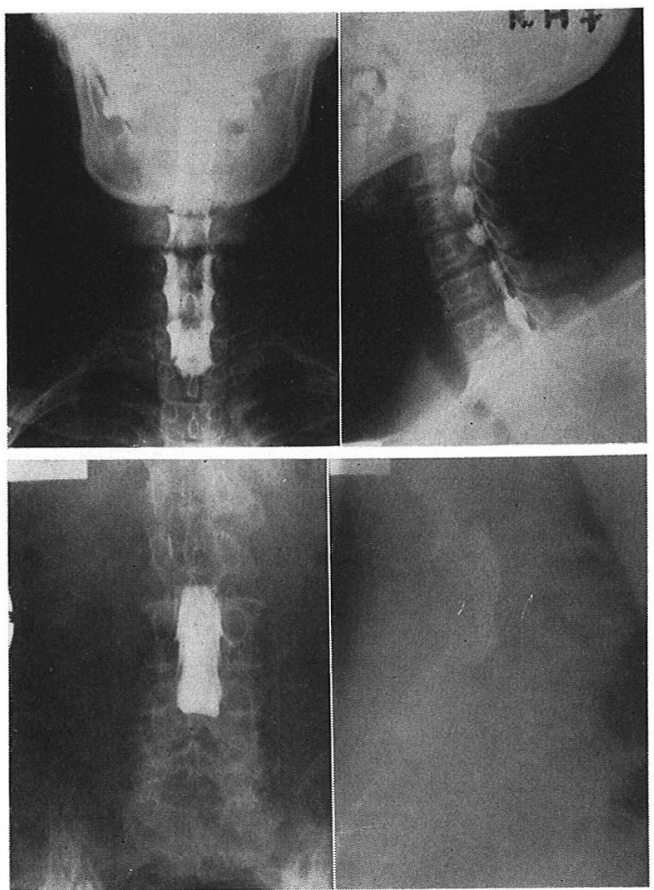

図 1. 症 例 1
ラムでは $\mathrm{L}_{4-5}$ kて完全ブロック認应り。また頸椎 部では $\mathrm{C}_{2-3}$ 上り $\mathrm{C}_{6-7}$ 間の多椎間に 造影所見の異常 を認める (図 1). 昭和 49 年 6 月, 腰椎部の椎弓切除 術を施行。術後, 下技症状は柽快したが, 頸部痛, 手 足のしびれ等が残存するため, 同年 8 月, 頸椎椎亏切 除術を実施した。てのような项椎症性脊喣症の合併例 では, 治療に際していずれの病変部を隻先すべきか, その判断に苫慮するととがある.

症例 2.61 才，女子，主婦．足底部難治性皮獻謴 瘍例. 14〜5 年前より下肢のしびれ，疼痛，間歇性跛 行があり, 昭和 49 年 4 月, 左足底部に潰瘍形成があ り，皮㱆形成術にても治瘾せず，難治性潰瘍となる。 昭和 50 年 3 月より 軽度の排永障害の出現および下肢 の疼痛, しびれが増強し, 昭和 50 年 3 月当科入院. 入院時, 腰痛, 下肢のしびれ, 疼痛, 排尿障害, 両足 部の軽度の知觉障害があり, 左足底部に瑟卵大の深い 潰瘍形成为諰められた。ミエログラムでは $\mathrm{L}_{3-4}$ 間以 下に買常所見を認め, 婹部春椎管狭寉による清瘍と判 断乙昭和 50 年 3 月, 椎弓切除術を施行. 術後, 主要

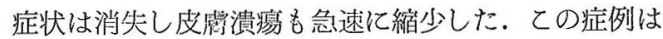
腰部, 下肢症状が軽度のために足底謴崵が本症に起因 するととが見過されていた症例である。

症例 3.55 才, 男子, 大工. 持続性陰䔄勃起例. 昭和 34 年, 外傷にて第 4 腰椎骨折々揨断され, 腰痛 が持続するために 2 年後脊椎固定術を受けた。以後症 状なく経過するも昭和 47 年より，腰痛と下肢痛が出 現し，昭和 48 年間歇性跛行と持続性陰茎勃起をきた 乙, 略和 49 年 7 月当科入院. 入院時, 持続性陰菱勃 起，陰茎のしびれ，下肢のしびれ，放散痛，下肢の症 督発作等があり, 知覚障害を右下渴外側部より足背全 体に，また両下肢に軽度の筋菱縮をみる。ミエログラ ムでは $\mathrm{L}_{4-5}$ 間で不完全停止像を示し, 䀡和 49 年 8 月, 椎亏切除術を施行. 術後, 除茎勃起としびれは完 全に消失し，主要症状もほぼ全治した。

症例 4.59 才, 男子, 農業. 再発例. 昭和 41 年頃 より下脑のしびれ，腰痛があり，炤和 49 年 10 月，症 壮が増強し間歇性跛行が著明となったため当科入院. ミエログラムでは，第 3 腰椎レベルで完全停止像を示 し, 昭和 49 年 12 月， $\mathrm{L}_{3,4,5}$ 椎弓切除術を受けた。術 後症状の消失定みたが, 昭和 50 月 9 月, 農作業に従 事したところ, 左下肢の脱力, 下重足, 右下肢のしび れなどが再発し，昭和 50 年 10 月，再入院．再入院 時，右下肢全体に知覚䤞嘛があり，PSR，ASR は左 
側で消失ないし低下を示した。 また左足関節むよび第 1 趾背屆打の著明な低下を認めた。再度のミエログラ ムでは, 前回のミエロで充盈のみられた $\mathrm{L}_{1}, \mathrm{~L}_{2}$ 高位 で, 不完全閉塞像を示し, また前回の手術で除圧した $\mathrm{L}_{3,4,5}$ 高位でも造影柱の細少化を認める(図 2 ). 手術 所見では，第 2 腰椎高位で硬膜は著明に絞扼され，前 回の除圧範囲が不十分であったと思われ，硬膜に小切 開を加えたが髅液の流出は認められず，馬尾神経の瘾 着が認められた.しかし $\mathrm{L}_{1,2}$ 腰椎椎弓切除後, 比較 的滥足な結果を得ている.
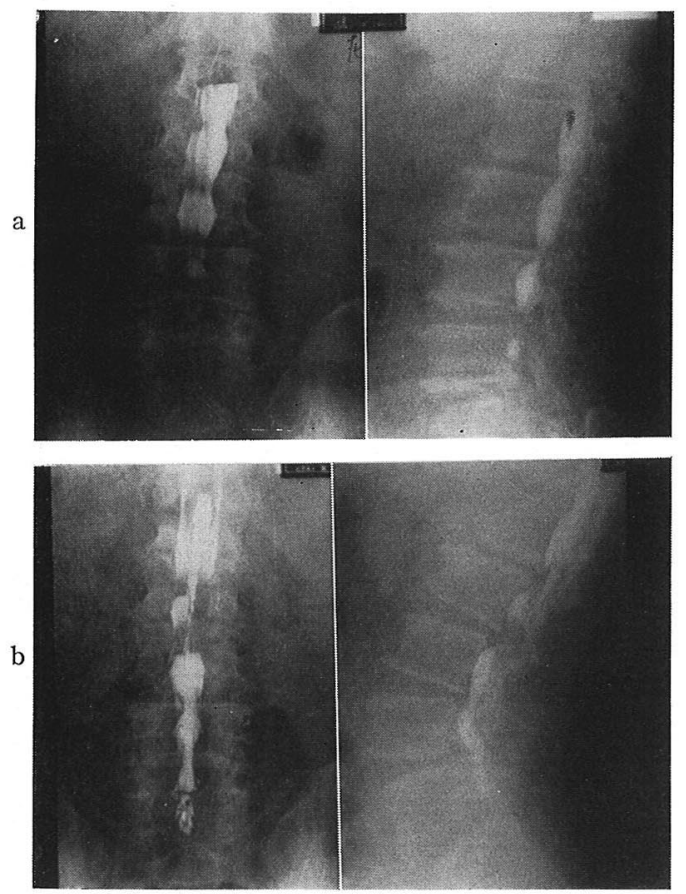

図 2, a. 第 1 回術前

b. 第 2 回術前

症例 5.56 才, 男子, 大工. 馬尾神経高度瘾着例. 18 才時より腰痛があり, 炤和 50 年 10 月より腰痛, 下肢放散痛, 脱力感, 間歇性跛行等が増強し当科保入 院. 入院時, 下肢犍反射の低下, 右下腿の筋棠縮, 足 趾の背属, 底屋力の低下および右膝部以下の下腿に知 覚障彗をみている，X線上，腰椎部に軽度の側彎と著 明な変形性所見を認め，ミュログラムでは $\mathrm{L}_{3-4}$ 間以 下にミエロ柱の wash-board 様烦を示した (図 3 ). 昭和 51 年 1 月, $\mathrm{L}_{2}$ より $\mathrm{L}_{5}$ までの椎马切除術を施行. 術中所見では，椎弓の高度の肥厚，硬化および击䩒帯
と硬膜の癒着等があり, 除圧後も硬膜の拍動なく硬膜 の小切開を施行するに馬尾神経は啝状を呈し, 広汎に 高度の癒着が認められた，術後，軽度の腰痛を残すが 他の症状は全く消失している.

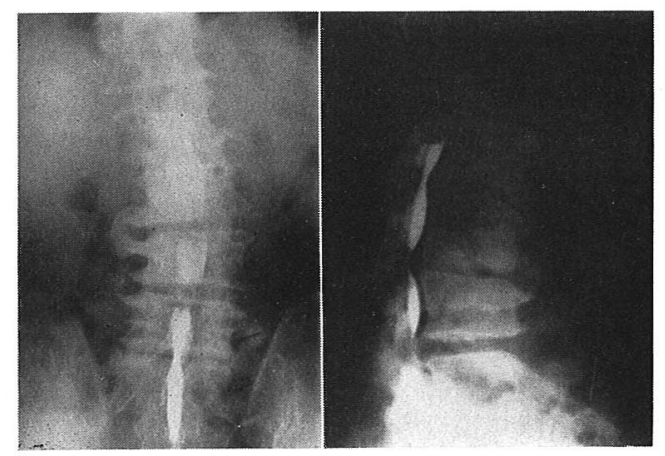

図 3. 症例 5

\section{総括および結語}

腰椎椎管;狭㾋の臨床症状は, 腰痛, 坐骨神経痛様疼 痛わよび間歇性跛行などが主要症状であるが，興味あ る症状として持続性陰茎, 勃起難治性潰煬等の種々の 馬尾神経圧迫症状をみられる. 本症の治療上の問題点 として,

1）頸椎症性脊鹃症との合併例も多くあり，てれら の症例ではその下肢症状がいずれの脊椎レベルに起因 するか，いずれの部位の手術を優先すべきかの洪定は 困難な場合もあり，十分な術前の検討が必要であろ 亏.

2）本症の観血的療法では，上下，左右への十分な 除圧が必要であると考えるが, 椎方切除後, 農業に従 事し再発をみた例があり, 手術後の腰椎部の保訬に十 分留意する必要があると思われる。

3）最近の症例で，ミクログラムで閏塞の著明な症 例, あるいは除圧後, 硬膜の拍動が得られない症例に おいて，硬膜に小切開を加え硬膜内を䚁祭している が, 馬尾神経の癐着を認める症例も多く, 中には照尾 が束状に㾙着しているものや，軟膜と強固な癒着が広 汎にみられる例もある.しかし剝離は無理に行なわず 硬膜を閂じているが，癒着が高度な例でも成績良好な ものもある。

文献

1) Clark, K.: J. Neurosurg., 31, 495, 1969. 
2) Ehni, G.: J. Neurosurg., 31, 490, 1969.

3) Ehni, G.: J. Neurosurg., 31, 507, 1969.

4) Epstein, J. A. : J. Neurol. Neurosurg. Psychiat. 25, 165, 1962.

5) 平光・ほか: 整形外科. $25,745,1974$.

6) 蓮江・ほか: 整形外科. $25,755,1974$.

7) 栗原・ ほ整形外科. 23, 202, 1972.

8）片岡・ほか：中部整災誌. 16, 835, 1973.

9） 円尾・ほ加：整形外科. 25, 755, 1974.

10）酒句・ほか：整形外科と災害外科. 24, 417, 1975.

11) Schatzker, J. et al. : J. Bone Joint surg., 50-B, 606, 1968.

12) Teng, P. et al.: Arch. Neurol., 8, 221. 1963.

13）竹光・ほか：中部整災誌. 16, 837, 1973.

14) Verbiest, H.: J. Bone Joint Surg., 36-B, 230, 1954.

15) Verbiest, H.: J. Bone Joint Surg., 37-B, $576,1955$.

16) Wilson, C. B. : J. Neurosurg. 31, 499, 1969.
17）若松・ほか：整形外科. 21, 1, 1970.

18）山田・ほ加：整形外科. $21,8,1970$.

翼 問山口大 服部 奖

昌趾に難治性濽瘍を呈した症例では，下肢の血管性 疾患はなかったのですか.

解 答麇児島大学 酒包 崇

下肢部の動脈血行不全は認められなかった。

質 問 九大整形 角的 信昭

Canda の瘾着と Lumbar spinal stenosis との関 連性があるか否か先生の御考えは?

解 答廐児島大学 酒旬 崇

癒着の所兒はミクログラムの閉塞の著明なもので 7 人の中 6 人にみられている.

\section{腰部脊椎管狭窄について術後馬尾神経障害と 再発をくり返した症例について}

熊本大学医学部整形外科学教室

$\begin{array}{lllllll}\text { 森 } & \text { 田 } & \text { 秀 } & \text { 明・成 } & \text { 尾 } & \text { 政 } & \text { 图 } \\ \text { 小 } & \text { 柳 } & \text { 英 } & \text { 一・前 } & \text { 川 } & \text { 清 } & \text { 継 } \\ \text { 栄 } & & \text { 輝 } & \text { 己・浦 } & \text { 門 } & & \text { 操 }\end{array}$

Investigation of Poor Cases after Operation for the Lumbar Spinal Stenosis

By

H. Morita, M. Naruo, E. Koyanagi, K. Maekawa,

T. Sakae and M. Urakado

Department of Orthopedic Surgery, Kumamoto University

Medical School, Kumamoto

We have a series of 110 patients with lumbar spinal stenosis who were treated by surgical procedure from September 1971 to March 1976.

In these series 4 cases revealed poor results. Poor cases and their causes are suggested as follows ;

1. A 42-year old woman with degenerative stenosis increased cauda equina lesion after operation with some recovery following wide laminectomy and facetectomy.

This case seemed to be caused in further damage of cauda equina due to transdural 